\title{
GEOLOGICAL AND GEOTECHNICAL INVESTIGATION OF ROAD FAILURES IN NIGERIA: A CASE STUDY OF PARTS OF IMO- ABIA STATES, SOUTHEASTERN NIGERIA
}

\author{
${ }^{1}$ Young Ezenwa Obioha, ${ }^{1}$ Alexander O. Selemo, ${ }^{2}$ Anulf Sowa and ${ }^{1}$ Johnbosco Nwagbara \\ ${ }^{1}$ Geosciences Research Team, School of Physical Sciences, Federal University of Technology \\ Owerri, Nigeria \\ ${ }^{2}$ Umwelttechnik, Western Germany
}

Corresponding Author: Phone: +234(0)8038774782; +234(0)80553408474; E-mail:

obiohe@yahoo.com

\begin{abstract}
Bad conditions of roads and their negative effects on environment and National development necessitated this research on road failures in parts of Imo and Abia States, Southeastern Nigeria, using integrated geological mapping, electrical resistivity measurements and geotechnical analyses, to determine geological factors causing road failures in these areas and proffer sustainable solutions to them. Results reveal the most complex deformations occurred in the Asu River Groups, Eze-Aku, Bende Ameki and Imo Shale formations. These formations consist of alternating sequences of incompetent rocks like clays, shales and mudstones, with resistivity range of $3.5 \mathrm{\Omega m}-22.0 \mathrm{\Omega m}$, occurring down to depths of $50.0 \mathrm{~m}$ in places. The in-situ moisture content ranges from 5.0-21.5\%, with mean of $13.25 \%$. Sieve analysis shows the lithology consists average fines $>80 \%$, sand $15 \%$, gravel $<3 \%$, are poorly graded and texturally immature. The drainage system is poor; the water table is shallow with low permeability, causing periodic swelling and shrinkage, which aggravate environmental deformation and road failure. In the northern parts of the area, the NNE - SSW trending faults and folded Okigwe - Abakaliki escarpment zone increases frequency of road failures. In the southern parts Aba, Owerri, Umuahia and Orlu failures are mainly due to unconsolidation, topography/slope instability, erosion and poor engineering practice. For effective performance and durability, pre-construction site investigation and materials standardization involving geologists, engineers and government is necessary. Improvement by surface / subsurface pumping techniques, suitable drainage systems, excavation, filling and stabilization with appropriate geo-textiles are suggested.
\end{abstract}

Keywords: Road failures, geological factors, environmental aesthesis, electrical resistivity measurements, sustainable solutions, complex deformations. 


\section{INTRODUCTION}

A road failure is the defective physical environmental condition that arises when a road and / or its pavement has developed cracks, flaked off, suffered face or surface defects, dissected, deformed, developed potholes, subsided and/or collapsed completely, thereby obstructing free flow of traffic. Hence the road can no longer serve the purpose for which it was constructed. The deplorable conditions of roads in Nigeria, particularly those in the southeastern parts of the country and their negative consequences on agricultural productivity, transportation and communication system, general environmental degradation, economic lose and national development necessitated the study of the geological and geotechnical factors affecting road failures in the country. Road failures can be classified into three broad headings based on their causative factors, these are: failures due to natural causes, failures due to anthropogenic activities, and failures occasioned by poor engineering design and construction. All roads are built on the earth surface which is composed of geological materials, hence, geology plays very vital roles in road pavement performance, stability and / or failures.

In addition to the three broad factors outlined above, methods of urbanization, settlements / land use system, poor agricultural practices, among others can also affect road failure. In recent years torrential rain-falls, flooding, gulling / mass movement, rising temperatures and pressures on the ecosystem, all threatening global environmental changes, combine to aggravate road failures in Nigeria and globally. The present study aims at contributing to solving this ravaging problem using integrated geological, geotechnical and geophysical approaches and proffering sustainable solutions to them.

\subsection{Consequences of Road Failures}

Geological factors causing road failures include all processes that are controlled by nature, such as physical, biological, chemical, mineralogical, weathering / erosional, hydrogeological processes, environmental and tectonic forces. These contribute to causing road failures, which have far reaching consequences on individuals, companies, local, state and national governments. These encompass high rates of accidents often occasioning death and high rate of fatality, esthetic menace, high cost of transportation / communication, reduced agricultural productivities, resulting in shortage and consequent high cost of food and living, environmental degradation and devastation, and many others. The study also aims at finding solutions and ways of ameliorating these socio-cultural and economic problems.

\subsection{Study Area}

The study area covers parts of the present Abia and Imo states and adjacent areas in Southeastern Nigeria (Fig.1). The area is situated in the tropical rain forest zone of the Niger Delta and Anambra -Afikpo Basins of Southeastern Nigeria sedimentary complex. Reyment (1965) defined this area as an extension of the Lower Benue Trough. The area is bound within Latitudes $4^{\circ} 40^{\prime}-6^{\circ} 30^{\prime} \mathrm{N}$ and Longitudes $6^{\circ} 30^{\prime}-8^{\circ} 30^{\prime} \mathrm{E}$ (Fig. 1). It comprises of an area of more than $12,689 \mathrm{~km}^{2}$, with high density of human population, and has many road networks which link it to other parts of the country. The prominent among which include the north-south Port Harcourt - Aba - Umuahia - Okigwe - Enugu Expressway, the Orlu Okigwe - Afikpo - Abakaliki Ogoja Highway and the Onitsha - Owerri - Aba - Calabar roads. The area is characterized by high annual rainfall range of $1500 \mathrm{~mm}$ to $2500 \mathrm{~mm}$, with mean daily temperature of about $27^{\circ} \mathrm{C}$, a high relative humidity of about $80^{\circ}$, and evergreen vegetation (Iloeje, 1971). The northern part of the area is composed of cuestas and plateau 
escarpments with steep slopes, while the southern part is relatively flat with gentle slopes. The area is drained by many rivers which include the Imo, Okitankwu, Orashi, Njaba, Otamiri rivers etc, forming a fairly trellis drainage pattern, with structurally controlled rivers running parallel to one another (Iloeje, 1971).

\subsection{GEOLOGICAL SETTING AND STRATIGRAPHY}

The geology of Southeastern Nigeria has been extensively studied (Kennedy, 1964; Reyment, 1967; Murat, 1970; Olade, 1975; Petters, 1978; Doust and Omatsola, 1989; Agumanu, 2009, 2011; Moshood et al., 2010; Obioha, 2018; Obioha et al., 2020) and many others. They show that the geology of Nigeria comprise about $50 \%$ sedimentary and $50 \%$ basement rocks. The stratigraphy of Southeastern Nigeria is summarized in Table 1. The Table shows that the sedimentary units in Southeastern Nigeria comprise about eleven Cretaceous to Tertiary lithostratigraphic formations, namely; Asu River Group, Eze Aku Shale, Awgu Shale, Nkporo Shale, Mamu Formation, Ajali Formation, Nsukka Formation, Imo, Bende Ameki, Ogwashi Asaba and Benin formations. These formations consist of alternating lithostratigraphic sequences of shales, sands, sandstones, clays, siltstones and lignites intruded by igneous bodies in places. The basement geology of southeastern Nigeria had also been investigated. Recently Ukwang (2009), Ekwueme (2010), Obioha and Ekwueme (2011), all recognized the area is characterized by high grade migmatites, gneisses, amphibolites and schists intruded by granitic rocks, dolerites and aplites.

\section{METHO DS OF STUDY}

The study involved both field investigation and laboratory analysis.

\subsection{Field Investigation}

The field work comprised geological mapping and geophysical measurements. The geological mapping and observation were carried out at the beginning of (March-April) and ending (October - November) of the rainy and dry seasons respectively for effective outcrop identification. Rock samples were collected with hand augers. Undisturbed samples were properly labeled, for easy identification during laboratory analysis. All samples for moisture content analysis were immediately put in the pre-weighed moisture content sample cans. All recognized fossil samples, their types, counts, diversity, genera, species and abundance were noted against point of collection. These enabled easy identification, analysis and interpretation of the depositional environment of the rocks. A total of 15 roads measuring about $1500 \mathrm{~km}$ were investigated, which represent a reasonable network of roads in the study area (Fig 1). The roads traverse all the geological formations in the study area southeastern Nigeria. 
Engineering Research Journal | ISSN: 2782-8212

Vol. 1, Issue 4 (April, 2021) | www.ijaar.org

Journal DOI: $\underline{\text { www.doi.org/10.46654/ERJ }}$

Article DOI: www.doi.org/10.46654/ERJ.1501

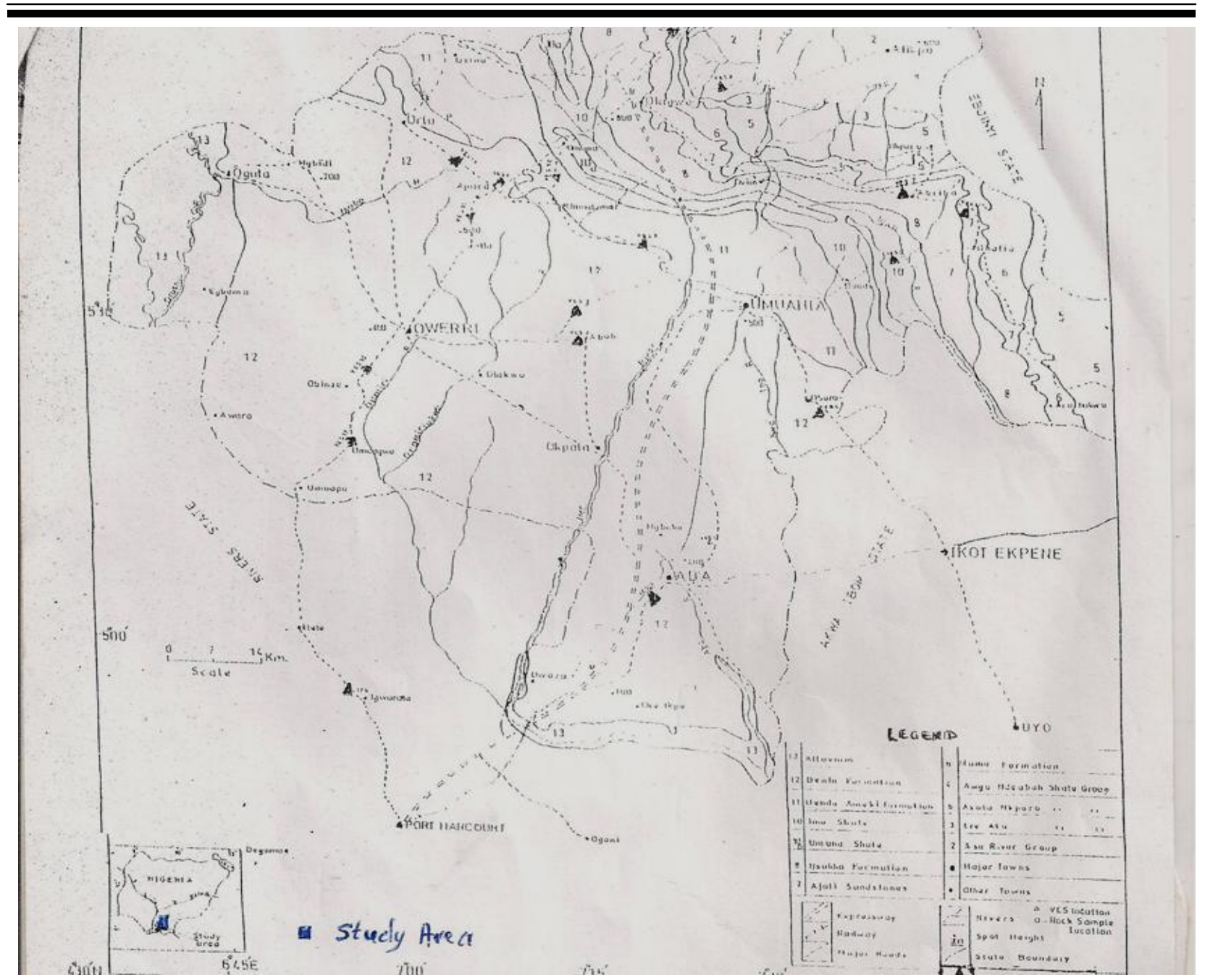

Fig. 1: Geological map showing the relationship between geology and road failure 
Table 1: Stratigraphy of study area, showing the relationship between Formations, Lithofacies and Road Failures.

\begin{tabular}{|c|c|c|c|c|}
\hline $\begin{array}{l}\text { PERIO } \\
\text { D }\end{array}$ & EPOCH & FORMATION & LITHOFACIES & ROAD FAILURE \\
\hline \multirow{3}{*}{$\begin{array}{l}\simeq \\
\simeq \\
\varangle \\
- \\
E \\
\simeq \\
\simeq \\
E\end{array}$} & $\begin{array}{l}\text { HOLOCENE- } \\
\text { OLIGOCENE }\end{array}$ & $\begin{array}{l}\text { Benin formation (BFM) } \\
\text { Ogwashi-Asaba } \\
\text { formation }(\mathrm{OAF})\end{array}$ & $\begin{array}{l}\text { Continental Fresh } \\
\text { Water Sands, Pebbly } \\
\text { Gravel, Silts, Clays, } \\
\text { Shales, Lignite series }\end{array}$ & $\begin{array}{l}\text { Ow-Orlu (OOr) } \\
\text { Ow-PH (Ow-PH) } \\
\text { PH-Umuahia-Okigwe } \\
\text { express way } \\
\text { (PAUOEW) } \\
\text { Owerri-Okigwe(Ow-Ok) }\end{array}$ \\
\hline & EOCENE & $\begin{array}{l}\text { Ameki Formation (BAF) } \\
\text { (Oshosun Formation)* }\end{array}$ & $\begin{array}{l}\text { Lignite series, Clays, } \\
\text { Sandstone, Limestone }\end{array}$ & $\begin{array}{l}\text { Umuahia-Bende (UmBr) } \\
\text { Umuahia-Ikot Ekpene } \\
\text { (UmIEr) } \\
\text { Orlu-Ideato (Or-Id) }\end{array}$ \\
\hline & PALEOCENE & $\begin{array}{l}\text { Imo State (ISH) } \\
\text { (Ewekoro Formation)* }\end{array}$ & $\begin{array}{l}\text { Laminated Shales, } \\
\text { Claystones, Limestone, } \\
\text { Marks and Calc. Sst }\end{array}$ & $\begin{array}{l}\text { Owerri-Okigwe (Ow-Okr) } \\
\text { Umuahia-Uzoabam } \\
\text { (Um-Uzr) }\end{array}$ \\
\hline \multirow{7}{*}{$\begin{array}{l}n \\
D \\
0 \\
{[1} \\
u \\
\varangle \\
= \\
\simeq \\
\simeq \\
u\end{array}$} & & $\begin{array}{l}\text { Nsukka Formation } \\
\text { (NF/UCM) } \\
\text { (Abeokuta Fm)* } \\
\text { (in west rest on } \\
\text { basement) }\end{array}$ & $\begin{array}{l}\text { Shales (dark grey), } \\
\text { Sandstone, Clays, Coal } \\
\text { Seams }\end{array}$ & $\begin{array}{l}\text { Okigwe-Leru-Lokpa- } \\
\text { Enugu Express way } \\
\text { (OLEEw) }\end{array}$ \\
\hline & $\begin{array}{l}\text { MAASTRICHT } \\
\text { IAN- } \\
\text { CAMPANIAN }\end{array}$ & Ajali Formation (AFM) & $\begin{array}{l}\text { F-M-C grained Sands, } \\
\text { xbd Friable Sandstone** }\end{array}$ & $\begin{array}{l}\text { Umuahia-Bende-Abriba- } \\
\text { Ohafia road (UBAOr) }\end{array}$ \\
\hline & & $\begin{array}{l}\text { Mamu Formation } \\
\text { (MF/LCM) }\end{array}$ & $\begin{array}{l}\text { F-M, xbd, sst, shales, \& } \\
\text { coal seams }\end{array}$ & $\begin{array}{l}\text { Umuahia-Bende-Abriba- } \\
\text { Ohafia road (UmBAOr) }\end{array}$ \\
\hline & & $\begin{array}{l}\text { Nkporo shale(NSH) } \\
\text { (Enugu Shale)* (angular } \\
\text { unconformity) }\end{array}$ & $\begin{array}{l}\text { Dark shales, mudstone, } \\
\text { with thin beds of } \\
\text { sandstone, with angular } \\
\text { unconformity** }\end{array}$ & $\begin{array}{l}\text { Leru-Enugu Express way } \\
\text { (LEEw); Okigwe-Afikpo } \\
\text { road (OAr) }\end{array}$ \\
\hline & $\begin{array}{l}\text { LOWER } \\
\text { SENONIAN }\end{array}$ & $\begin{array}{l}\text { Awgu Shale } \\
(\text { AGS)**(Makurdi } \\
\text { Formation) } * * \text { Awgu } \\
\text { Ndeaboh Shale }\end{array}$ & $\begin{array}{l}\text { Well beded shale, blue- } \\
\text { grey cale, sandstone and } \\
\text { shally } 1^{\text {st }}\end{array}$ & $\begin{array}{l}\text { Not Traversed (or not } \\
\text { Recognized but occurs off } \\
\text { Okigwe-Leru-Enugu } \\
\text { Region }\end{array}$ \\
\hline & TURONIA & $\begin{array}{l}\text { Ezeaku Formation (ESH) } \\
\text { (Odukpani Formation)* }\end{array}$ & $\begin{array}{l}\text { **Hard grew-black } \\
\text { shales, silts, sst and sdy, } \\
\text { shale }\end{array}$ & $\begin{array}{l}\text { Ishiagu-Ezeaku-Amasiri- } \\
\text { Afikpo (IEAAR) }\end{array}$ \\
\hline & $\begin{array}{l}\text { CENOMANIA } \\
\text { NA-LBIAN }\end{array}$ & Asu River Group (ARG) & $\begin{array}{l}\text { Thick Shales, } \\
\text { fossiliferous } 1^{\text {st }} \\
\text { (Ammonite, Forams, } \\
\text { Echinoderm) }\end{array}$ & $\begin{array}{l}\text { Abakaliki-Ogoja } \\
\text { (Ab-OR) }\end{array}$ \\
\hline
\end{tabular}

(Key: *Modified after Desauvogie and Fayose, 1970. **Modified after Reyment, 1965).

\subsection{Geophysical Studies}

The Geophysical surveys were carried out at more complex road failure locations to further characterize the rocks and structure of the formations. A total of 30 geo-electric stations were occupied. The vertical electrical sounding (VES) technique was adopted using Schlumberger array. The field geophysical principles and techniques were based on Al-Sadi, (1980), Dobrin and Savit, (1988) and Telford et-al (1988). The VES studies enabled determination of the variability in litho-depth, structures and their horizontal distribution within the study area. Selected representative geo-electric curves of the VES surveys are presented (Figs: $2 a-2 d$ ). 


\subsection{Geotechnical studies}

Geotechnical studies were carried out, which include sedimentation analysis, liquid limit, plastic limit, and plasticity index tests. Also determined were the texture, grading and sorting of the various rock samples, using the mechanical sieving techniques. The laboratory techniques and Interpretation were based on the ASTM (1990). BS-1377 (1990), AASHTO (1986) and BS 5930 (1981) Laboratory procedures. The uniformity coefficient (CU) was determined based on the technique after Casagrande $(1932,1947)$. The unified soil classification scheme (USC) was used in the grading and classification of the soil.

\subsection{RESULTS}

\subsection{Geological}

The results of the field geological survey of road failures in parts of SE Nigeria are summarized in (Tables 1 and 2). Table 1 shows the relation that at Ajata - Ibeku along Umuahia - Bende Road in the Bende - Ameki Formation (BAF). The road was built on dark brown silty shales. The rocks are often weathered and ferruginized and range from less than $2 \mathrm{~m}$ to $5 \mathrm{~m}$ thickness The silty shale is directly underlain by very thick $(\sim 40 \mathrm{~m})$ deposit of clays, as indicated by the geologic cross section and corroborated by the geo-electric measurement (Fig. 3). These lithofacies are nearly horizontally bedded, striking NW-SE ( $0-$ $30^{\circ}$ ) and dipping gently SE at about $1^{\circ}$ to $4^{\circ}$. The road runs across a natural divide with seasonal streams draining in NE and SW directions away from the divide. More than $340 \mathrm{~m}$ of the roads here have failed, subsided and collapsed to depths of more than $1 \mathrm{~m}$ to $5 \mathrm{~m}$, thus making traffic flow very difficult. Some vehicles follow cut off tracks. The water table is shallow and the drainage system poor due to the impermeability of the clay and the underlying shale and claystone sequences. The cracks, subsidence and / or collapse are inferred to result from repeated compaction and cyclic swelling and shrinkage of the clay minerals and related rocks. The summarized geological mapping results are presented in (Table 2).

\subsection{Geophysical}

The results of electrical resistivity measurements carried out are presented in (Figs. $2 \mathrm{a}-\mathrm{d}$ and Tables 2 a-d). They show that the region consists of about three to seven geo-electric layers, with resistivity range of $3.5 \mathrm{ohm}-\mathrm{m}$ to about $250 \mathrm{ohm} \mathrm{m}$, occurring down to depths of about $0.4 \mathrm{~m}$ to $112 \mathrm{~m}$ (Fig. 2), indicating alternation of competent litho-logs mainly sandstones and gravels sequences with the incompetent rocks such as clays, shales and mudstones (which are prone to seasonal swelling and shrinkage during rainy and dry seasons) in most of the locations, thus causing further deformations and failures of the roads. The geotechnical analysis result (Table 3) corroborates. The geophysical finding shows that the in-situ moisture content ranges from minimum of 5.52\% in the Ajali Formation (AF) in Bende area, along Ohafia - Bende Road (OBR), through 14.36\%, $14.81 \%$ in the Nsukka and Mamu formations respectively at Okigwe - Water works along Okigwe - Umuna - Owerri Road (OUR) and around Lokpaukwu - Lokpanta along Port-Harcourt - Aba - Okigwe - Enugu Expressway. 


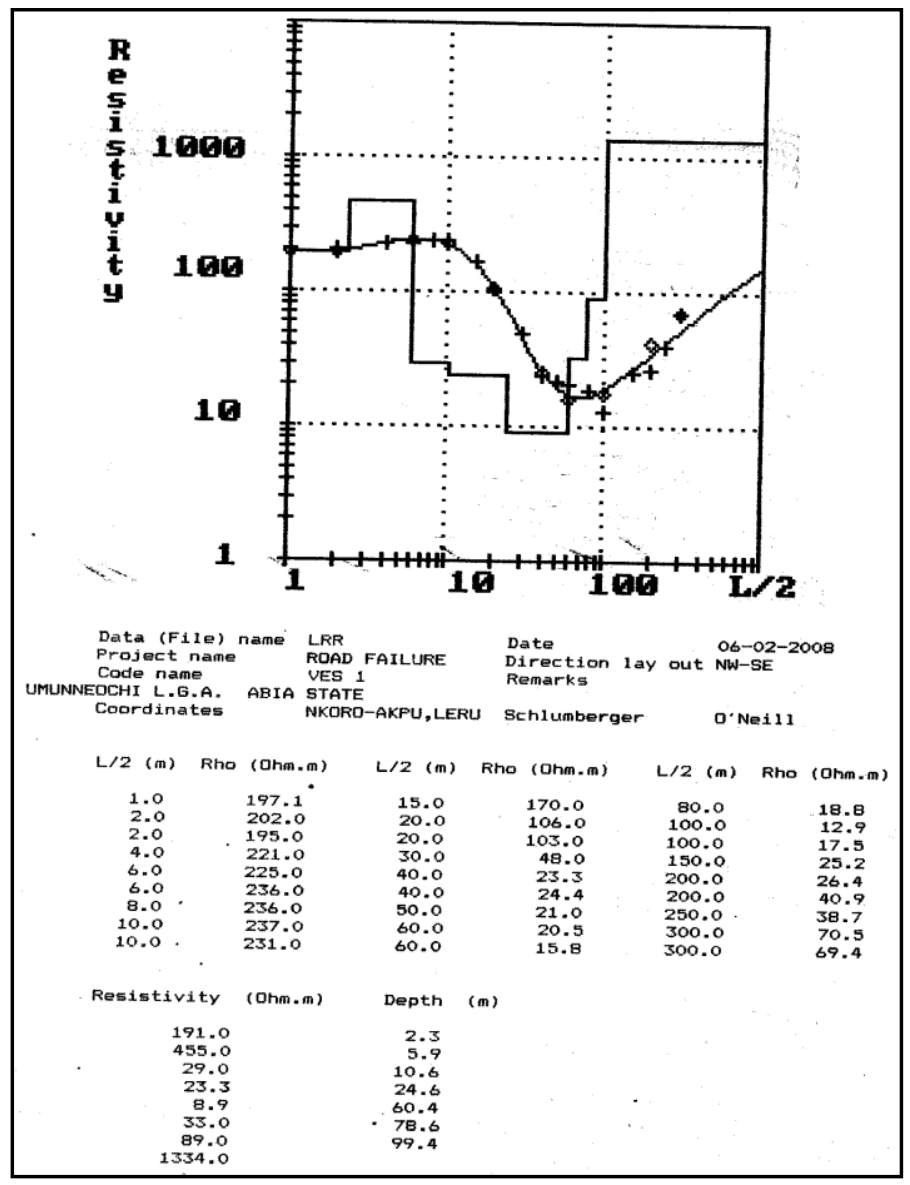

Fig. 2 A/Table 2Da:. VES survey at Nkwerre along Owerri-Orlu Road

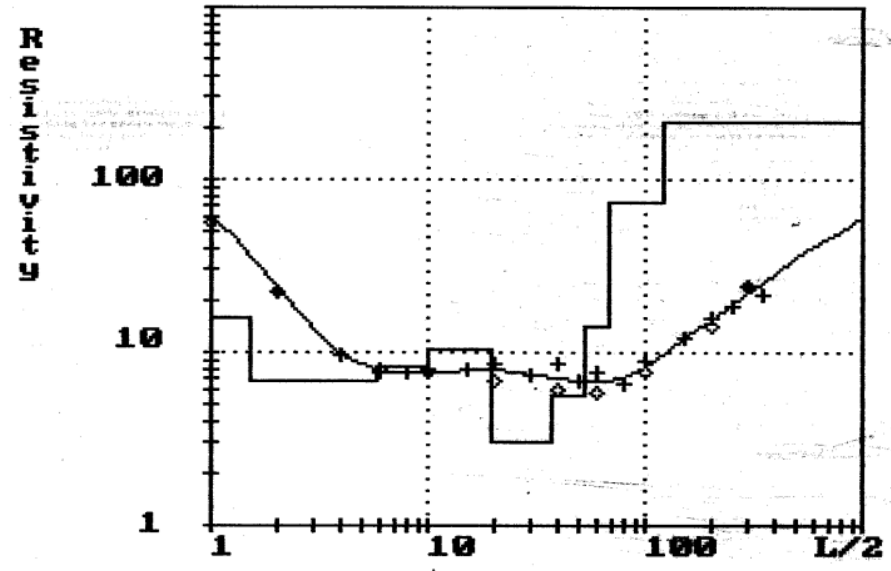

$\begin{array}{lll}\begin{array}{ll}\text { Data (File) name } \\ \text { Project name }\end{array} & \text { DGB } & \text { Date } \\ \text { ROAD FAILURE } & \text { Direction 1ay out NE-SW }\end{array}$ OKIGWE L.G.A. IMO STATE

Coordinates
SChlumberger

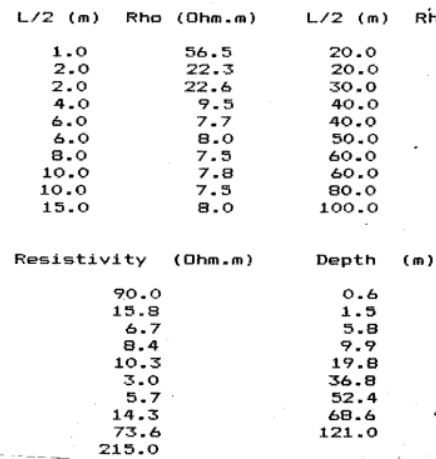

Fig. 2 B/Table 2dB. VES survey at Okigwe-Enugu Road 


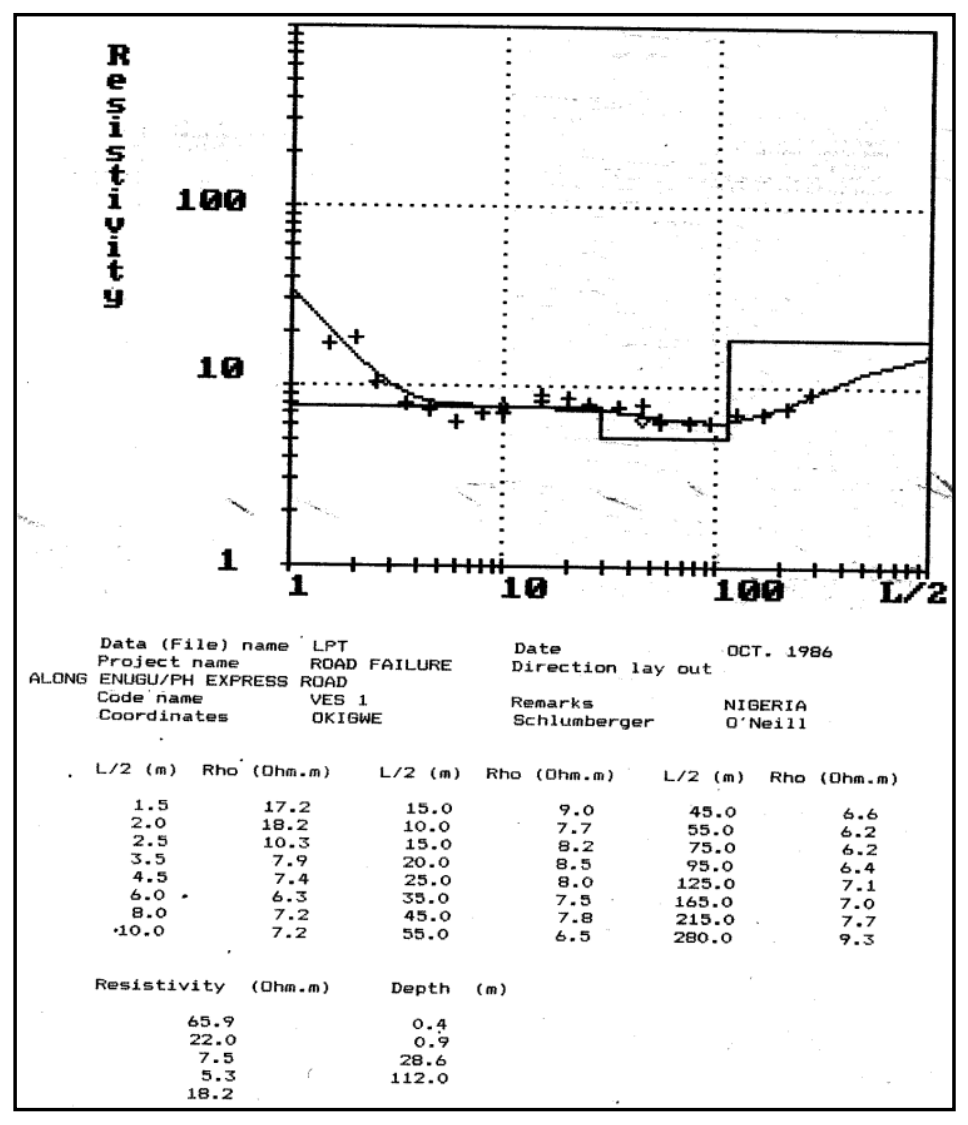

Fig. 2 C. /Table 2c: VES survey at Enugu Port Harcourt Express Way

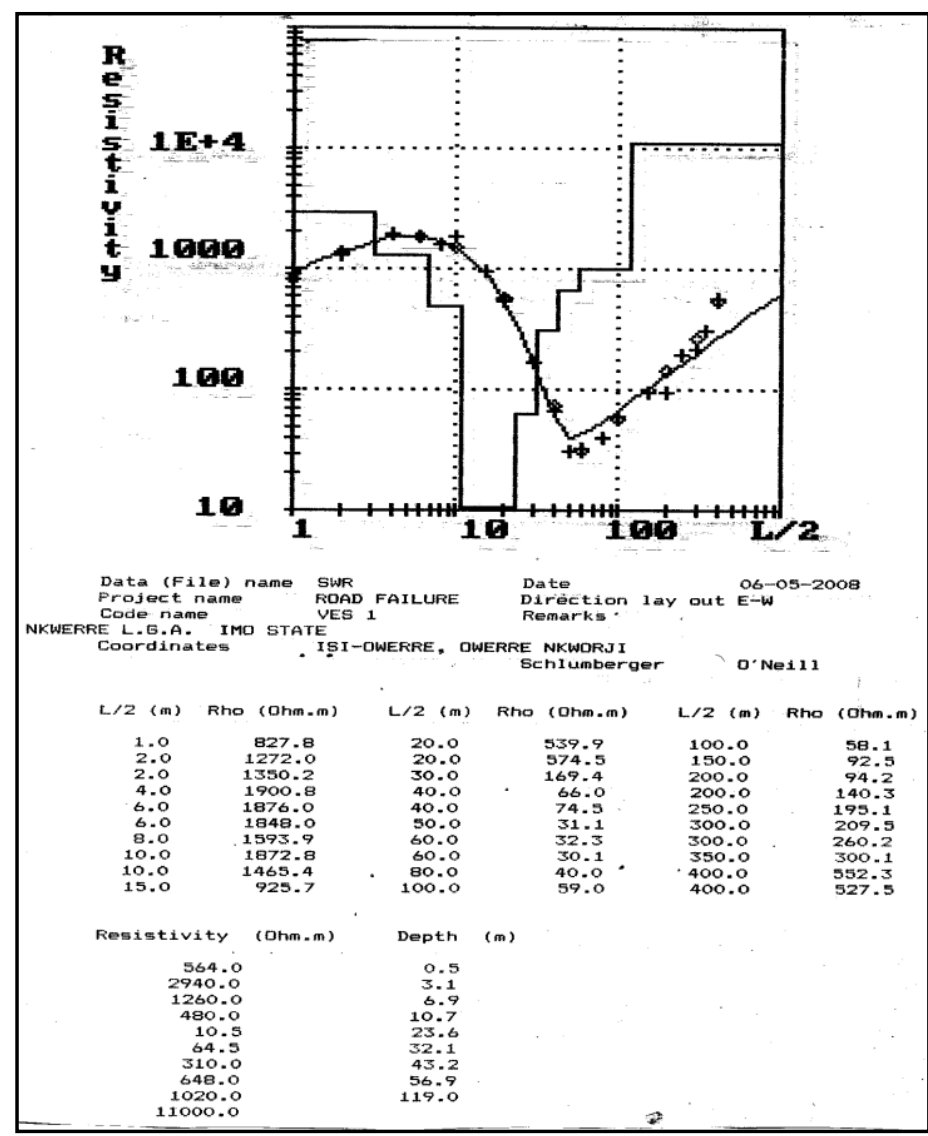

Fig. 2 D/Table 2d: . VES survey at Isi- Owerre Nkworji along Orlu-Umuahia Road

\subsection{Geotechnical Result}

The mechanical sieve analysis result shows that the Bende- Ameki Formation at Ajata Ibeku along Umuahia Bende Road (UBR) is poorly sorted and poorly graded, with more than $88 \%$ fines (Table 3). The Ameki Formation at Umuahia (sample UB1) shows uniform grading, poorly sorted (Table 3 ), with mean grain size of $0.001-1.2 \mathrm{~mm}$, which indicates clay + silt + sand mixture. 
Journal DOI: www.doi.org/10.46654/ERJ

Article DOI: www.doi.org/10.46654/ERJ.1501

Table 3: Summary of Geotechnical Results

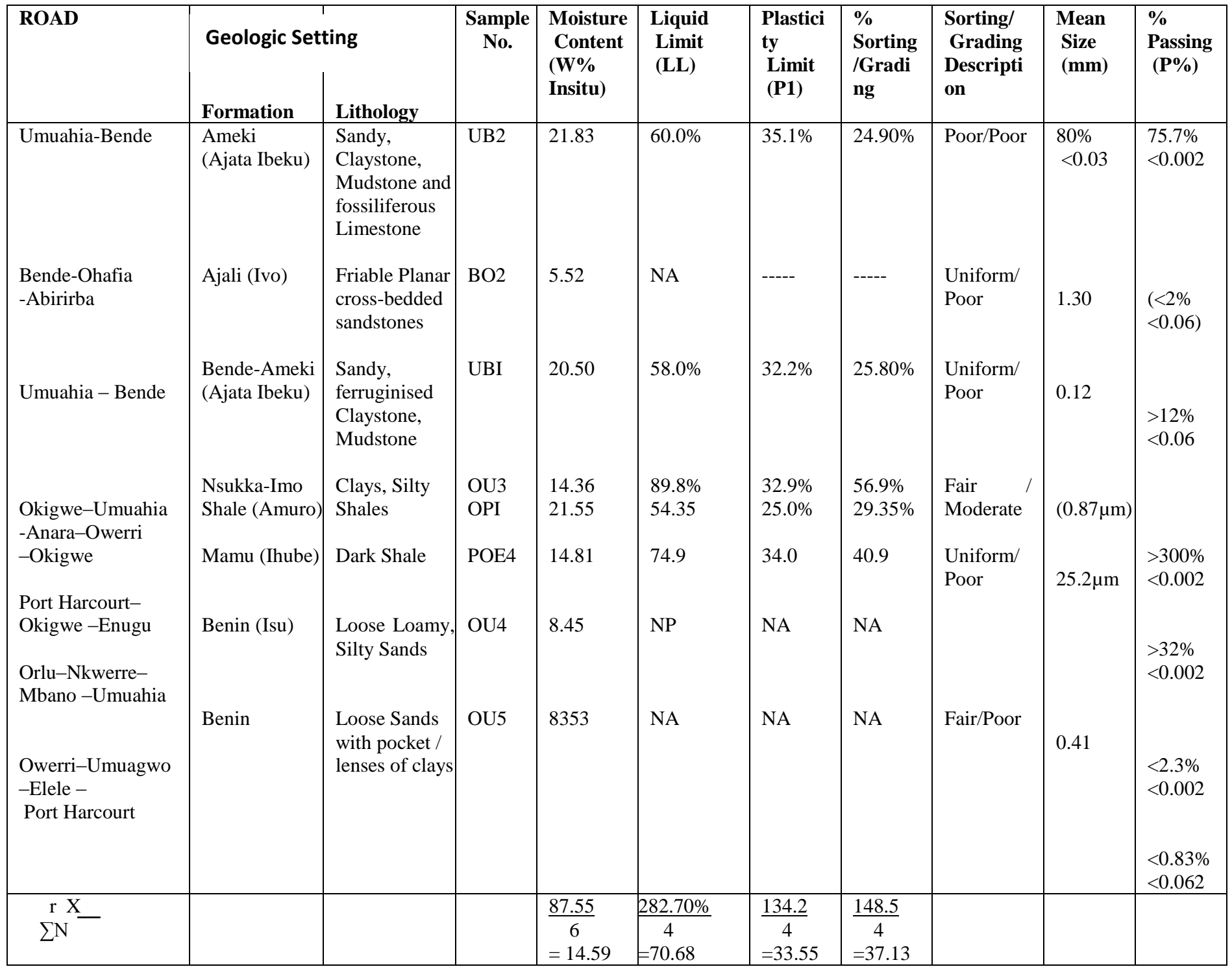




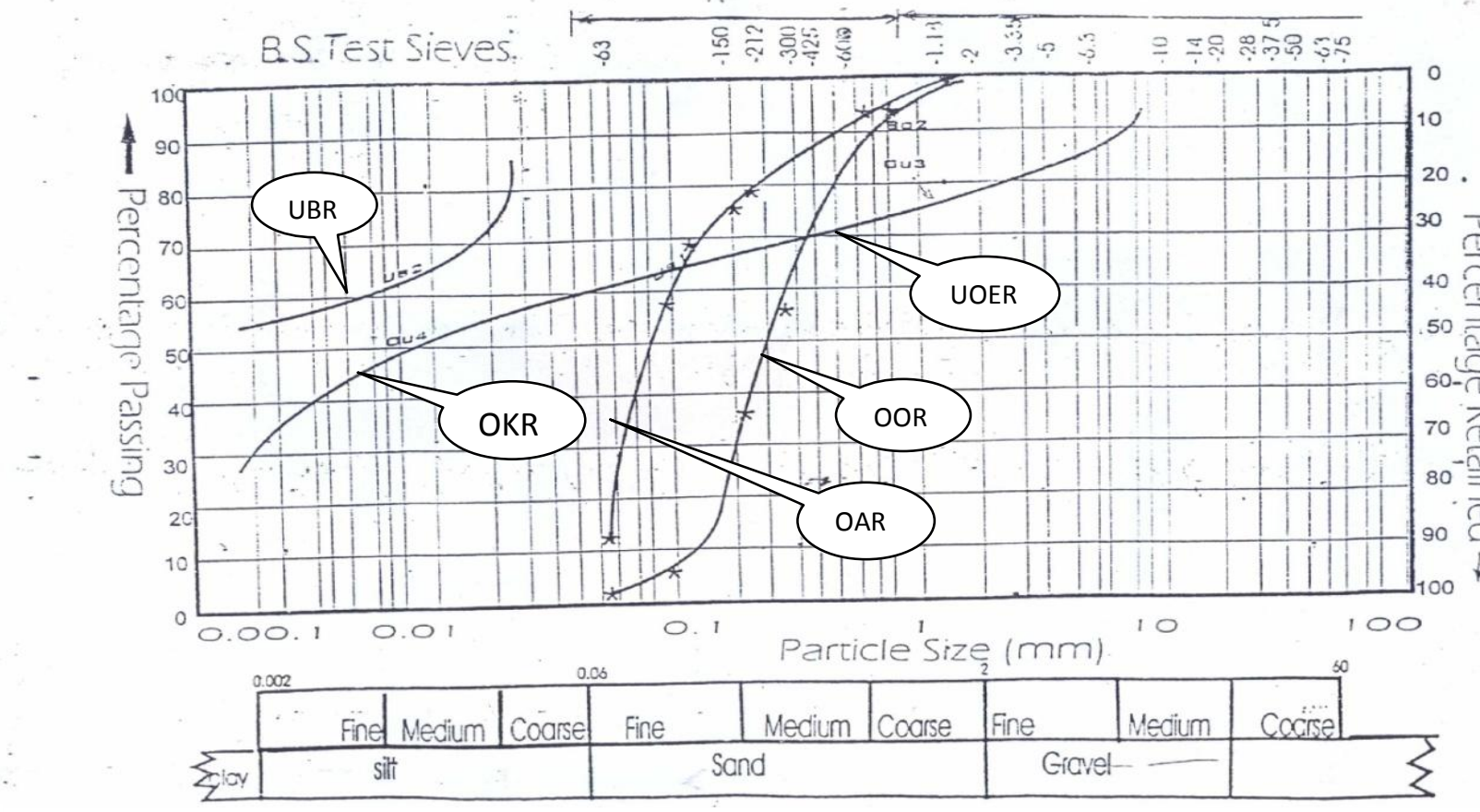

KEY: OAR $=55 \%$ Clay; $30 \%$ Silt; UOER $=32 \%$ Clay; $28 \%$ Silt; $18 \%$ Sand; $14 \%$ Gravel. UBR $>88 \%$ Fines, OOR $=>98 \%$; OKR $=60 \%$ fines

Fig. 5: Grading Chart for Soil Samples including Hydrometer/Sedimentation Tests; for soils collected along more complex deformation sites in the study.

The Nsukka Formation at Okigwe water works along Owerri - Okigwe (OOR) has more than $60 \%$, shows fair grading, moderate sorting and mean grain size of $1.27 \mathrm{~mm}$, which indicates that it is composed mainly of fine to medium grained sand, sandstones and gravels (Fig. 3). These occur in alternating sequences with the incompetent rocks such as clays, shales and mudstones, which are prone to seasonal swelling and shrinkage during rainy and dry seasons, in most of the locations, thus causing further deformations and failures of the roads. This corroborates the geological and geophysical results. The Ajali Formation at Ihube along Umuahia - Okigwe - Enugu (UOER) consists $32 \%$ clay; $28 \%$ silt; $18 \%$ sand; $14 \%$ gravel is uniformly graded, poorly sorted and has a mean grain size of $1.3 \mathrm{~mm}$, indicating that it is predominantly composed of fine to medium grained sands (Table 3, Fig. 5). The hydrometer analysis (Table 3) shows that the Bende Ameki Formation around Ajata Ibeku along Umuahia Bende Road (UBR) and the Nsukka Formation around Okigwe water works Owerri - Okigwe road (OOR) shows 32\% finer that 0.002 and $0.0012 \mathrm{~mm}$ mean diameter, and $57 \%$ finer than 0.002 and $0.00186 \mathrm{~mm}$ mean diameter respectively.

\subsection{Discussion}

Result of the road investigations (Tables 1, 2, 3, 4 and Figs. 1, 2, and 3) reveal that road failures occur most in areas where the terrain consists mainly of sequences of incompetent, soft impermeable rock materials of shales, clays (mainly montmorillonite, kaolinite and 
smectite) and mudstones. This includes Eze-Aku Shales (ESH), Mamu Formation (MF/LCM), Nsukka Formation (NF/UCM), Imo Shales (ISH) and Bende-Ameki Formations (BAF).

Table 4: Summarized Result of Field Survey Conditions of the Road.

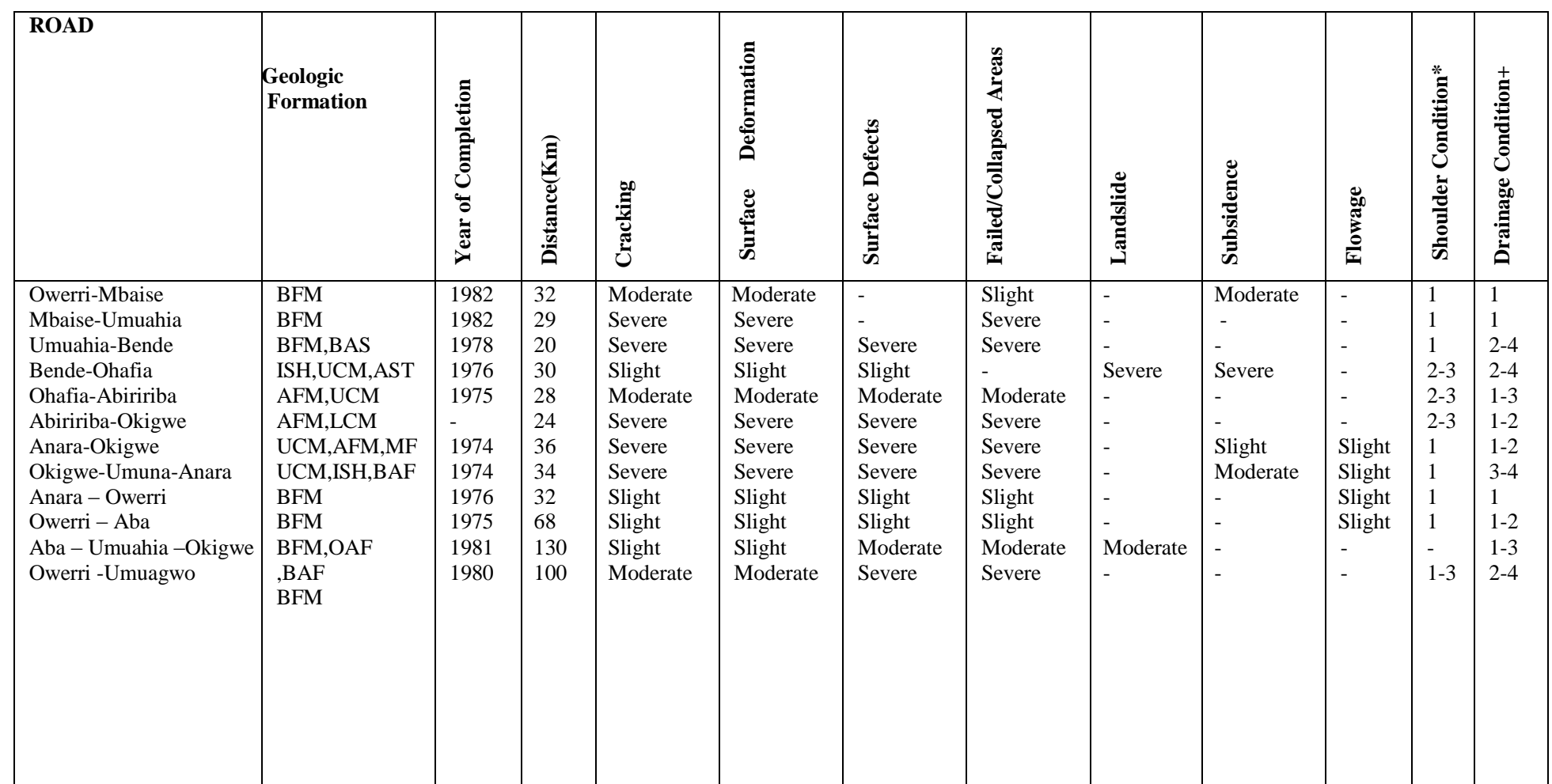

ARG = Asu River Group; ESH = Ezeaku Shale Formation; AGW = Awgu Formation; NSH = Nkporo Shales; MF/LCM = Mamu Formation / Lower Coal Measures; AFM = Ajali Formation; UCM = Nsukka Formation/Upper Coal Measures; ISH = Imo Shales; BAF = Bende - Ameki Formation / Owerri Coastal Plain Sands. These characteristics are based on the International Association of Engineering Geologist (LAEG) Specifications. The Laboratory Procedures were based on the American Standard for Testing and Materials (ASTM) Specifications. * Based on number, depth, length, aerial extent/ coverage and degree of dissection by erosion, shoulder condition is hereby classified into three; 1 . Slightly,2. Moderate 3. Severe dropped and defected. + Similarly, drainage condition have been classified into five; (a) no defect-0 (b) slightly defect -1 (c) moderately defected -2-3 (d) severely defected-4 (e) blocked -5 .

Table 4 summarizes the relation between geology/lithology and defective conditions of the roads; including the Geologic Formation, Distance covered $(\mathbf{K m})$, Cracking, Surface Deformation, Surface Defects, Failed/Collapsed Areas, Landslide, effects Flowage, Shoulder drops and Drainage Conditions. The sieve analysis (Fig. 5) shows that the roads consists of $>55 \%$ clay and $30 \%$ silt (i.e. $85 \%$ fines average). These include Bende-Ameki road (BAR), Umuahia-Okigwe-Enugu Expressway (UOER), is underlain by high percentage of fines, lesser amount of sand and least \% gravel. Some roads such as Owerri - Aba road (OAR) consisting more than $88 \%$ sand, while the Orlu-Owerri road (OOR) consists more than $>98 \%$ sand, hence deformation on these roads are due to unconsolidation and erosion and fracture. Comlex road failures also occur in areas of alternating sequences of competent / 
incompetent rocks such as clays, shales or mudstones alternating with sandstone and gravel, as were observed along Owerri-Amuro-Okigwe road, Aba-Ikot Ekpene and Umuahia- IkotEkpene roads. However, road failures were also observed in some areas composed of competent rocks like sandstones, conglomerates and siltstones. In such areas; failures were inferred to be due to differential hydraulic conductivity of the rocks/soil layers ahd unconsolidation of rock materials and thir friable nature.

Some failures are attributed to high rate of fracturing, folding, slope instability and unconsolidation of rock materials, faulting, and poor engineering design and construction. Such failures occur mainly in form of potholes, face/surface defects, shoulder drop off, crack and subsidence. For example along Owerri Aba road, Owerri-Onitsha road, Port-HarcourtAba-Umuahia-Okigwe road. The study revealed that severe erosion, gulling and mass movement were the main factors causing failures, along Okwelle-Dikenafia-Isiekenesi road, built on the Benin/Ogwashi - Asaba, Bende Ameki Formations. The results show that the geological, geophysical and geotechnical findings agree and corroborate one another.

\subsection{Conclusion}

The study revealed that southeastern Nigeria consists of very complex geology which plays very vital roles in pavement performance. Of the $1,500 \mathrm{~km}$ of road network studied; more than $80 \%$ had failed. More than $50 \%$ of the failed roads are inferred to result from geological factors/controls; about $40 \%$ are due to anthropogenic factors and or lack of maintenance, while the remaining $10 \%$ are due to poor agricultural practices and engineering construction. The results show that road failures occurred most in the areas underlain by thick sequences of incompetent rocks with low resistivity, such as claystones, shales, lignites and mudstones. These lithofacies include zones underlain by the Asu River Groups, Ezeaku Shales, and Imo Shales followed by Bende-Ameki Formations and least in the Ajali and Benin Formations, which are composed of more competent rocks like sands and sandstones. The incompetent litho units have characteristically high porosity, low permeability and low hydraulic conductivities, which make them prone to cyclic swelling, shrinkage and periodic flooding, thus causing very rapid deformation of the rocks. Also the investigation revealed that mass movement, erosion, land-slide, and gulling and subsidence are prime factors contributing to road / pavement failure, particularly where the pavement is underlain by unconsolidated or friable rocks. Apart from esthetics, environmental degradation and devastation, road failures have far reaching negative consequences on transportation / communication, agriculture and food production, general economy and national development.

\subsection{RECOMMENDATION}

The study recommends the following as measures capable of improving, controlling or at least ameliorating these socio-economic problems weighing down our national development and growth due to road failures.

Where thick sequences of incompetent rocks like claystones, mudstones and / or shale form the bedrocks, such materials should be scrapped /excavated to depth of at least $4 \mathrm{~m}$ and imported geo-textile used to refill the site before compaction operations. Where the sub-grade rock is too thick to be completely scrapped off, upgrading of the materials or soil treatment can be achieved by cementation or application of limestone, which is locally obtainable from Sokoto, Ewekoro, Nkalagu and many other locations in Nigeria. In areas of flooding and shallow water table, surface pumping techniques and drainage constructions can be applied to reduce flooding and maintain uniform subsurface pressure. In areas of complex topography 
and steep slopes, leveling must ensure that angle of safety is not exceeded during construction.

\section{ACKNOWLEDGEMENT}

We sincerely acknowledge the technical advices of Prof. E.G. Akpokodje of Geology Department, University of Port Harcourt Nigeria, and Eze Prof. B.A. Nwachukwu of the Department of Civil Engineering, School of Engineering and Engineering Technology (SEET), Federal University of Technology Owerri. Prof. P.0. Okeke of the Nigeria Coal Cooperation Enugu, and Dr. M.A. Nwachukwu of the School of Environmental Technology, Federal University of Technology Owerri, are highly appreciated for their assistance during the Field Geologic mapping and Instrumentation. We wish to acknowledge the University of Montreal Canada for the use of their Geotechnical Guide. We appreciate the efforts of Miss Ogazi Scholastica and Miss Ozotta Ogochukwu for typesetting the manuscript. 


\section{REFERENCES}

AASHTO-1986: American Association of State Highway and Transportation Official Standardspecification for construction materials and methods of sampling and testing, $14^{\text {th }} \mathrm{ed}$. Washington, D.C

Agumau, A. E. 2009. Storm influenced tidal epeiric seas. An example from the Cretaceous of Southern Benue Trough, Nigeria. Global Journal of geological Sciences, 7 (2), 151- 170 .

Agumau, A. E. 2011. Environment of deposition of the Awgu Formation (Late

Cretaceous), Southern Benue Trough, Nigeria. Global Journal of Geological Sciences, 9, (2), 215-228.

AL-Sadi, N. H. 1980. Seismic Exploration Techniques and Processing. Iraq National Oil Company, Stuttgart. P. 14-204.

ASTM D4318-84, 1990. American Society for Testing and Materials. Annual Book of ASTM Standards, Vol.04-08, Soil and Rock Building Stones.

BS1377, 1990. Methods of testing for Civil Engineering purpose (part 2). British Standard Institute, London. $\quad$ Manual of Soil laboratory Testing - K.H. Head, p. 1-58.

BS5930, 1981. Code of Practice for Site Investigation. British Standard Institute, London, part 4.

Casagrande, A. 1932. Research on the Atterberg Limits of Soil, Public Road, Vol. 13, No. 8, 121- 136.

Casagrande, A. 1947. Classification and Identification of Soils. Processes American Society of Civil Engineers. Vol.73, No. 6, part 1.

CRBDA 1982. Cross River Basin Development Authority 1982, whether / forecast and monitoring report.

Dobrin, M. B. and Savit, C. H. 1988. Introduction to Geophysical Prospecting, $4^{\text {th }}$. Edition. McGrawhill Book Company, New York, USA. 58-495 p.

Doust, H. and Omatsola, E. M. (1989). Niger Delta in divergent passive margins. America Association of Petroleum Geologists (AAPG), Bulletin 68 (3). 201 - 238.

Ekwueme, B. N. 2010. The Pan African Event of Southeastern Nigeria - A Review. Nigerian Mining and Geosciences Society, Calabar-2010, Abstract Vol.

Kennedy, W. O. 1964. The structural differentiation of Africa in the Pan-African $( \pm 500$ M.Y) episode. Research Institute African Geology, Leads, $8^{\text {th }}$. Annual Report. 48- 49.

Iloeje, N. P. 1971. A New Geography of Nigeria. Nigeria, Longman Nigeria Limited.

Moshood, N. T., Matthew, E. N. and Ryuji, K. 2010. Textural and geochemical characteristics of the Ajali Sandstones, Anambra Basin, Southeastern implication for its provenance. Comptes Rendus Geoscience, 342, 136-150. 
Murat, R. C. 1970. Stratigraphy and Paleo-geography of the Cretaceous and Lower Tertiary in Southern Nigeria. In: T. F. J. Dessauvagie and A. J. Whiteman (eds.), African Geology, Ibadan, Ibadan University Press, 251-276.

Obioha, Y. E. 2018. Ba-Pb Mineralization In Ugwuajirija Ishiagu Area, Lower Benue Trough, Southeastern Nigeria: Geochemical Evidence. Global J. of Pue \& Applied Sci. Vol. 24, pp. 161-170.

Obioha, Y. E. and Ekwueme, B. N. 2011. Petrology and chemical composition of gneisses of Northwest Obudu Plateau, Southeastern Nigeria. Global Journal of Pure and Applied Sciences, 17 (2), p. 215 -226.

Obioha, Y. E. Okeke, O. C. and Israel, H. 2020. Environmental Aspects Of Solid Mineral Resources Development In Nigeria: An Overview. Int. J. of Adv. Acad. Research. (IJAAR). Vol.6. Issue 1jan. 2020. Pp. 82-94.

Olade, M. A. 1975. Evolution of Nigeria's Benue Trough (Aulacogen): a tectonic model. Geol. Mag., 112, 575-581.

Petters, S.W. 1978. Mid-Cretaceous paleoenvironments and biostratigraphy of the Benue Trough, Nigeria. $\quad$ Bull. Geol. Soc. America. 89, 151-152.

Reyment, R. A., 1967. Aspects of the Geology of Nigeria. The Stratigraphy of the Cretaceous and Cenozoic Deposits. Ibadan University Press. P. 1-181.

Telford, W. M., Geldert, I. R., Sheriff, R. E. and Keys, D. A. 1988. Applied Geophysics. Cambridge University Press, London,400-804p.

Ukwang, E. and Ekwueme, B. N. 2009. Geochemistry and geotectonic study of granitic rocks, Southwest Obudu Plateau, southeastern Nigeria. Journal of Mining and Geology. 45, 1, 73-82. 